\title{
CARACTERIZAÇÃO DE GENÓTIPOS DE MIRTILO UTILIZANDO MARCADORES MOLECULARES ${ }^{1}$
}

\author{
SERGIO DELMAR DOS ANJOS E SILVA ${ }^{2}$, LUIS EDUARDO CORREA ANTUNES ${ }^{3}$, DENILSON GOUVEA ANTHONISEN ${ }^{4}$, \\ JULIANA SILVALEMÕES ${ }^{5}$, EMERSON DIAS GONÇALVES ${ }^{6}$
}

RESUMO- O cultivo do mirtilo está em expansão no Brasil, em especial em regiões de clima temperado, onde há grande demanda em relação a cultivares adaptadas às condições edafoclimáticas regionais. O objetivo deste trabalho foi caracterizar genótipos de mirtilo do programa de melhoramento da Embrapa Clima Temperado, utilizando marcadores moleculares do tipo RAPD e SSR. Foram caracterizados 40 genótipos de mirtilo por RAPD e oito cultivares por microssatélites. Os nove primers utilizados na técnica de RAPD geraram 89 marcadores. A similaridade genética entre os genótipos variou de 64 a 89\%. Utilizando a similaridade média (66\%), foram obtidos quatro grupos. Foram gerados 11 marcadores a partir de três pares de primers de microssatélites. A similaridade genética entre as cultivares variou de 25 a $75 \%$. Com similaridade média (42,4\%), foram obtidos três grupos. Com apenas três pares de primers de SSR, foi possível definir o padrão das oito cultivares de mirtilo, revelando a eficiência da técnica de microssatélite na caracterização de genótipos dessa espécie. Esses resultados revelam a eficiência dos marcadores tipo RAPD e SSR na caracterização de genótipos de mirtilo. Entretanto, os marcadores tipo microssatélites geram resultados mais precisos, sendo os mais recomendados para uso em programas de melhoramento e identificação de cultivares.

Termos para indexação: RAPD, SSR, Vaccinium.

\section{CHARACTERIZATION OF BLUEBERRY GENOTYPES USING MOLECULAR MARKERS}

ABSTRACT- The blueberry crop planting area is increasing in Brazil, especially in Temperate Climate Zones, generating demands relating to suitable cultivars adapted to regional climate and soil conditions. This work aimed to characterize blueberry genotypes from Embrapa Clima Temperado breeding program, using RAPD and SSR molecular markers. There were characterized 40 blueberry genotypes using RAPD and 8 cultivars using SSR molecular markers. The 9 RAPD primers generated 89 markers. The genetic similarity ranged from 64 to $89 \%$. Through the average similarity (66\%), it was possible to identify four groups. The three pairs of SSR primers generated 11 markers. The genetic similarity among cultivars ranged from 25 to $75 \%$. With a similarity average of $42,4 \%$, it was generated three groups. It was possible to define the pattern of the eight blueberry cultivars using only three pairs of SST primers, which shows the efficiency of SST technique when characterizing blueberry genotypes. These results reveal that both RAPD and SSR are efficient to characterize genotypes of this specie. However, SSR markers are more accurate and, therefore, recommended for use in breeding programs and cultivars identification.

Index Terms: RAPD, SSR, Vaccinium.

\section{INTRODUÇÃO}

O mirtilo (Vaccinium spp) é uma espécie frutífera pertencente à família Ericaceae, subfamília Vaccinoideae e gênero Vaccinium, originária da Europa e América do Norte. Seus frutos apresentam significativo valor de mercado, devido ao sabor exótico, seu valor econômico e suas propriedades medicinais. A fruta é considerada como "fonte de longevidade", fator que se deve, especialmente, ao alto conteúdo de antocianinas, substâncias que beneficiam a visão, a pele, os vasos sangüíneos e ajudam em casos de varizes, hemorróidas, problemas circulatórios, transtornos cardíacos, feridas externas e internas, edemas, artrites e artroses. Além disso, suas propriedades nutracêuticas e, principalmente, oportunidades de negócio têm despertado a atenção de técnicos e produtores de frutas do Brasil (Raseira \& Antunes, 2004).

O cultivo do mirtilo (Vaccinium spp) está em franca expansão em países da América do Sul, como Chile, Argentina e Uruguai (Strick, 2005; Bañados, 2006), pois há uma grande demanda dos países do Hemisfério Norte, entre os quais os Estados Unidos, por mirtilos frescos na contra-estação de produção daquelas regiões, o que gera uma oportunidade de negócio muito interessante para o setor produtivo brasileiro.

${ }^{1}$ (Trabalho 099-07). Recebido em: 11-04-2007. Aceito para publicação em: 19-09-2007.

${ }^{2}$ Embrapa - Centro de Pesquisa Agropecuária de Clima Temperado, Caixa Postal 403, CEP 96001-970 Pelotas- RS. E-mail: sergio@cpact.embrapa.br ${ }^{3}$ Embrapa - Centro de Pesquisa Agropecuária de Clima Temperado, Caixa Postal 403, CEP 96001-970 Pelotas- RS. Bolsista CNPq. E-mail: antunes@cpact.embrapa.br.

${ }^{4}$ Embrapa - Centro de Pesquisa Agropecuária de Clima Temperado, Caixa Postal 403, CEP 96001-970 Pelotas- RS. E-mail: denilson@cpact.embrapa.br ${ }^{5}$ Embrapa - Centro de Pesquisa Agropecuária de Clima Temperado, Caixa Postal 403, CEP 96001-970 Pelotas- RS. Bolsista CNPq. E-mail: julianalemoes@terra.com.br.

${ }^{6}$ Embrapa - Centro de Pesquisa Agropecuária de Clima Temperado, Caixa Postal 403, CEP 96001-970 Pelotas- RS. Bolsista CNPq/RD. E-mail: emersondg@hotmail.com. 
Os trabalhos com mirtilo no Brasil iniciaram em 1983, na Embrapa Clima Temperado (Pelotas-RS), com a introdução da coleção de cultivares de baixa exigência em frio do grupo 'rabbiteye' (olho- de-coelho), oriundas da Universidade da Flórida (Estados Unidos). O plantio comercial iniciou em 1990, na cidade de Vacaria (RS).

Atualmente, estima-se a produção de mirtilo em cerca de 60 toneladas, concentradas nas cidades de Vacaria e Caxias do Sul (RS), Barbacena (MG) e Campos do Jordão (SP), totalizando uma área de aproximadamente 35 ha. A região de Vacaria foi pioneira no cultivo dessa espécie e é a grande referência em termos de produção (Raseira \& Antunes, 2004). Segundo o Instituto Brasileiro de Fruticultura (IBRAF, 2006, citado por Antunes \& Madail, 2007), em 2002, o Brasil exportou cerca de quatro toneladas de mirtilo, o que representou uma receita de US\$24.000,00 aos produtores e divisas para o Brasil. Trata-se de um número pouco significativo, face ao potencial natural que o País oferece à produção comercial.

Segundo Longley (1927) e Newcomber (1941), citados por ECK (1966), o número básico de cromossomos da espécie é 12 (x =12). O mirtilo é nativo da América do Norte, Estados Unidos e Canadá, onde é denominado "blueberry".

Galletta \& Ballington (1996) classificam os tipos de mirtilo comercialmente plantados em cinco grupos importantes: o grupo 'Highbush' (arbusto alto), que possui variedades que necessitam geralmente entre 650 e 850 horas de frio abaixo de $7,2^{\circ} \mathrm{C}$; o grupo 'Half high' (arbusto de médio porte), que envolve híbridos de $V$. angustifolium e V. corymbosum L.; o grupo 'Southern highbush' (arbusto de porte alto, originário do sul dos Estados Unidos), o qual engloba plantas de baixa necessidade em frio, com predomínio da espécie $V$. corymbosum $(4 \mathrm{x}=48)$ '; o grupo 'Rabbiteye' (olho-de-coelho - espécie hexaplóide) $(6 \mathrm{x}=72)$, cujas plantas podem alcançar de dois a quatro metros de altura, com as seguintes características: vigorosas, longevas, produtivas, possuem tolerância ao calor e à seca, baixa necessidade em frio, produzindo frutos ácidos, firmes e de longa conservação; o grupo 'Lowbush' (arbusto de pequeno porte), no qual as plantas têm menos de meio metro de altura. A maioria delas pertence à espécie $V$. angustifolium, embora esteja neste grupo, também, o mirtilo do Canadá ( $V$. myrtilloides e $V$. boreale $)(2 \mathrm{x}=24)$.

Para a adoção de um sistema de certificação de mudas, além de aspectos inerentes à sanidade, a identidade genética das variedades é imprescindível para a garantia da qualidade da muda e respaldo para o produtor, que está adquirindo o produto que melhor the convém. A variabilidade fenotípica observada nas plantas pode ser devido a variações no genótipo, a variações no efeito de ambiente e na resposta diferencial de alguns genótipos ao ambiente. Para uma caracterização mais eficiente, é necessário o uso de técnicas moleculares que permitem identificar o polimorfismo entre indivíduos a partir do DNA e associar a gene de grande efeito.

No estudo de variabilidade genética entre espécies de mirtilo utilizando microssatélites, Broches et. al. (2004) observaram que os primers VcEST23 e VcEST169 produziram fragmentos facilmente identificáveis, afirmando que poderão ser muito úteis na análise de diversidade genética e identificação de cultivares. Trabalhos já realizados com marcadores RAPDs mostraram que é possível estudar a diversidade genética de ameixeiras (Shimada et al., 1999; Ortiz et al.,1997), de acerola (Salla et al., 2002), de castanha (Galderisi et al., 1998) e de maçã (Dunemann et al., 1994).

Em função das poucas informações encontradas na literatura e com a finalidade de subsidiar o programa de melhoramento genético e identificação de cultivares de mirtilo, o objetivo deste trabalho foi o de caracterizar genótipos de mirtilo do programa de melhoramento da Embrapa Clima Temperado, utilizando marcadores moleculares RAPD e SSR.

\section{MATERIAL E MÉTODOS}

Utilizando-se de marcadores tipo RAPD e SSR, foram caracterizados genótipos de mirtilo cultivados na Embrapa Clima Temperado, Pelotas-RS. Através da técnica de RADP, 40 indivíduos foram caracterizados: oito cultivares (Tabela 1), duas seleções e 30 plantas individuais pré-selecionadas. Para a amplificação, foram utilizados nove oligonucleotídeos com 10 bases, sintetizados pela Operon Technologies, selecionados em função do polimorfismo. Os primers selecionados foram A-1, A8, A-17, A-4, I-7, A-2, C-6, A-11e Y-20.

A extração do DNA foi realizada segundo método CTAB (Brometo de cetiltrimetilamônio), descrito por Ferreira \& Grattapaglia (1998), e as reações de amplificação foram realizadas segundo protocolo descrito pelos mesmos autores, em um volume total de $13 \mu \mathrm{L}$ de mix contendo tampão $(1 \mathrm{X}), \mathrm{MgCl}_{2}(3 \mathrm{mM})$, dNTPs $(0,2 \mathrm{mM})$, BSA purificada $(5 \mu \mathrm{g})$, primer $(15 \eta \mathrm{g})$, taq DNA polimerase (1U) e DNA genômico (20ๆg). As amplificações foram realizadas em tubos de $200 \mu \mathrm{L}$ em termociclador programado para 40 ciclos de um minuto a $92^{\circ} \mathrm{C}$, um minuto a $35^{\circ} \mathrm{C}$ e dois minutos a $72^{\circ} \mathrm{C}$, seguidos de uma extensão final de cinco minutos a $72^{\circ} \mathrm{C}$.

Os produtos das reações de amplificação foram separados por eletroforese em gel submerso de agarose a $1,5 \%$, com brometo de etídio $(25 \mu \mathrm{g})$, onde migraram $8 \mathrm{~cm}$ sob diferença de potencial de $110 \mathrm{~V}$. A revelação dos fragmentos foi efetuada em câmara escura, sob luz ultravioleta.

A partir da identificação dos fragmentos amplificados, foram construídas matrizes binárias de similaridade, baseadas na presença (1) e ausência (0) de bandas, que foram analisadas no programa NTSYS (Numerical Taxonomy and Multivariate Analysis for Personal Computers), versão 2.0, utilizando o coeficiente de Jaccard e o método da média aritmética nãoponderada.

As cultivares que constam na Tabela 1 foram caracterizadas através de marcadores de microssatélites, utilizando 3 pares de oligonucleotídeos (Tabela 2). A extração do DNA foi realizada pelo método CTAB (Brometo de cetiltrimetilamônio), descrito por Ferreira \& Grattapaglia (1998). As reações de amplificação foram realizadas segundo protocolo descrito por Rowland et al. (2003), em um volume total de $25 \mu \mathrm{L}$, de tampão (2X), $\mathrm{MgCl}_{2}(1,8 \mathrm{mM})$, dNTPs $(0,2 \mathrm{mM})$, BSA purificada $(5 \mu \mathrm{g})$, primer $(0,5 \mu \mathrm{M})$, taq DNA polimerase (1U) e DNA genômico (20ๆg). As amplificações foram realizadas em tubos de $200 \mu \mathrm{L}$, em termociclador programado para um ciclo de três minutos a $92^{\circ} \mathrm{C}$, 
40 ciclos de quarenta segundos a $92^{\circ} \mathrm{C}$, setenta segundos a $56^{\circ} \mathrm{C}$ e dois minutos a $72^{\circ} \mathrm{C}$.

Os produtos das reações de amplificação foram separados por eletroforese em gel submerso de agarose a 3,5\%, com brometo de etídio $(25 \mu \mathrm{g})$, onde migraram $10 \mathrm{~cm}$ sob diferença de potencial de $110 \mathrm{~V}$. A revelação dos fragmentos foi efetuada em câmara escura, sob luz ultravioleta.

A partir da identificação dos fragmentos amplificados, foram construídas matrizes binárias de similaridade, baseadas na presença (1) e ausência (0) de bandas, que foram analisadas utilizando o programa NTSYS (Numerical Taxonomy and Multivariate Analysis for Personal Computers), versão 2.0, sendo adotado o coeficiente de Dice e o método da média aritmética não-ponderada para a determinação dos grupos.

\section{RESULTADOS E DISCUSSÃO}

Na técnica de RAPD, foram gerados 89 marcadores a partir dos nove primers utilizados (Tabela 3), com polimorfismo igual a $74 \%$. Burgher et al. (2002), trabalhando com mirtilos do tipo "lowbush", utilizando 11 primers, obtiveram polimorfismo de $53 \%$, enquanto Salla et al. (2002), trabalhando com acerola, obtiveram $91 \%$ de polimorfismo, utilizando 37 primers. A etapa de seleção desses marcadores é fundamental para a eficiência dos trabalhos de caracterização, podendo ser feita através de revisão bibliográfica ou testes no laboratório.

A similaridade genética entre os genótipos analisados variou de 64 a 89\% (Figura 1). Utilizando a similaridade média (66\%), foram obtidos quatro grupos. Burgher et al. (2002) obtiveram resultados semelhantes, utilizando 11 primers, com similaridade média de $70 \%$, gerando seis grupos.

Como observado na Figura 1, o primeiro grupo, com similaridade mínima de $69 \%$, reuniu genótipos oriundos do programa de melhoramento da Embrapa Clima Temperado. No segundo grupo, ficou isolado o genótipo 68 , também obtido do programa de melhoramento local, enquanto no terceiro foram agrupadas as cultivares Climax, Bluegem, Powderblue, Delite e Bluebelle, além do genótipo 70, com similaridade mínima de 68\%. No último grupo, foram reunidos os demais genótipos e as cultivares Aliceblue, Briteblue e Woodard, com similaridade mínima de $68,5 \%$. Esses dados caracterizam a variabilidade genética dentro dos grupos, indicando possibilidades de obtenção de material superior através de cruzamento e seleção.

Os resultados demonstram a eficiência da técnica do RAPD para a caracterização de genótipos de mirtilo.

Para as oito cultivares de mirtilo caracterizadas através da técnica de microssatélite, foram gerados 11 marcadores a partir dos três pares de primers utilizados (Tabela 4). A similaridade genética entre os genótipos analisados variou de 25 a $75 \%$ (Figura 2). Utilizando a similaridade média $(42,4 \%)$, foram obtidos três grupos. No primeiro grupo, foram reunidas as cultivares Florida, Florida M, Bluebelle, Bluegem e Climax, no segundo, Woodard e Powderblue, e no terceiro, Briteblue e Delite. Analisando a Tabela 4 e a Figura 2, verifica-se que, utilizando apenas três pares de primers, foi possível definir o padrão das oito cultivares de mirtilo avaliadas, revelando a eficiência de marcadores microssatélites na caracterização de genótipos dessa espécie. Outros trabalhos realizados através dessa técnica também obtiveram bons resultados não só para mirtilo, mas também para outras espécies (Graham et al., 2002; Rowland et al., 2003; Ahmad et al., 2003).

Os resultados obtidos neste trabalho mostram a eficiência das duas técnicas na caracterização de genótipos de mirtilo. Entretanto, a técnica de microssatélites gera resultados mais precisos, sendo a mais recomendada para uso em programa de melhoramento e identificação de cultivares.

TABELA 1 - Procedência e material de origem de cultivares de mirtilo caracterizadas através da técnica de RAPD e SSR. Embrapa Clima Temperado, Pelotas-RS, 2007.

\begin{tabular}{|c|c|c|}
\hline Cultivares & Procedência & Material de origem \\
\hline Florida $\mathrm{M}^{*}$ & - & - \\
\hline Aliceblue** & Gainesville, Flórida & polinização livre de 'Beckyblue' \\
\hline Bluebelle & Tifton, Geórgia & 'Callaway' e 'Ethel' \\
\hline Bluegem & Gainesville, Flórida & $\begin{array}{l}\text { polinização livre de uma seleção chamada Tifton } \\
31 \text {. }\end{array}$ \\
\hline Briteblue & Tifton, Geórgia & \\
\hline Climax & Tifton, Geórgia,. & 'Callaway' e 'Ethel' \\
\hline Delite & Geórgia & Seleções T14 e T15. \\
\hline Powderblue & Beltsville, Maryland., & 'Tifblue' e 'Menditoo', \\
\hline Woodard & Tifton, Geórgia & 'Ethel'e 'Callaway'. \\
\hline
\end{tabular}

* Não caracterizada por RAPD ** Não caracterizada por SSR.

TABELA 2 - Seqüência dos Primers de microssatélite utilizados na caracterização de cultivares de mirtilo. Embrapa Clima Temperado, Pelotas-RS, 2007.

\begin{tabular}{cc}
\hline \multicolumn{1}{c}{ Primers } & Seqüência de bases (5'-3') \\
\hline \multirow{2}{*}{ M56 } & AAA TTG CTC GCA AAC CAA TC \\
& TTT TCC AAG CAA GGG ATG G \\
M910 & \\
& AAT GGA AAG AAG CTC TGA CA \\
M12 & ATC AGC CTC AGA TCC ACC AC \\
& CTT TGC CAA GTT CTG GTT GA \\
& GCT AAA TGA AGT GCG GGA GA \\
\hline
\end{tabular}

TABELA 3- Polimorfismo apresentado pelos Primers selecionados na caracterização de genótipos de mirtilo através da técnica de RAPD. Embrapa Clima Temperado, Pelotas-RS, 2007.

\begin{tabular}{|c|c|c|c|c|}
\hline \multirow[b]{3}{*}{ Identificação } & \multirow{3}{*}{$\begin{array}{l}\text { Primer } \\
\text { Seqüência de bases }\end{array}$} & \multicolumn{3}{|c|}{ Marcadores } \\
\hline & & \multirow{2}{*}{$\begin{array}{c}\text { Total } \\
\text { n. }^{\circ}\end{array}$} & \multicolumn{2}{|c|}{ Polimórficos } \\
\hline & & & $\mathrm{n.}^{\circ}$ & $\%$ \\
\hline OPA-1 & CAGGCCCTTC & 17 & 15 & 88,2 \\
\hline OPA-8 & GTGACGTAGG & 17 & 14 & 82,4 \\
\hline OPA-17 & GACCGCTTGT & 11 & 9 & 81,8 \\
\hline OPA-4 & AATCGGGCTG & 10 & 8 & 80,0 \\
\hline OPI-7 & CAGCGACAAG & 10 & 6 & 60,0 \\
\hline OPA-2 & TGCCGAGCTG & 8 & 3 & 37,5 \\
\hline OPC-6 & GAACGGACTC & 6 & 5 & 83,3 \\
\hline OPA-11 & CAATCGCCGT & 5 & 3 & 60,0 \\
\hline OPY-20 & AGCCGTGGAA & 5 & 3 & 60,0 \\
\hline Total & & 89 & 66 & \\
\hline
\end{tabular}


TABELA 4- Padrão de marcadores gerados pelos primers de microssatélite M56, M910 e M12 para as cultivares de mirtilo avaliadas. Embrapa Clima Temperado, Pelotas-RS, 2007.

\begin{tabular}{l|ccc|cccc|ccccc}
\hline \multicolumn{1}{c}{ Primer } & \multicolumn{3}{c|}{$\mathbf{1 2}$} & \multicolumn{3}{c|}{$\mathbf{5 6}$} & \multicolumn{5}{c}{$\mathbf{9 1 0}$} \\
\hline \multicolumn{1}{c}{ Marcador } & 531 & 527 & 517 & 550 & 546 & 541 & 302 & 300 & 298 & 296 & 294 \\
\hline \multicolumn{1}{c}{ Genótipo } & & & & & & & & & & & \\
\hline Florida M & + & - & - & - & - & - & - & + & - & + & - \\
Woodard & + & - & - & + & - & - & + & - & + & - & - \\
BriteBlue & - & + & - & - & + & - & - & + & + & - & - \\
BlueBelle & - & - & + & - & - & + & - & + & - & + & - \\
Climax & - & + & - & - & - & + & - & - & + & + & - \\
Bluegem & - & - & + & - & - & + & - & - & + & + & - \\
PowderBlue & - & - & + & + & - & - & - & - & + & - & + \\
Delite & - & + & - & - & + & - & - & - & + & - & + \\
\hline
\end{tabular}

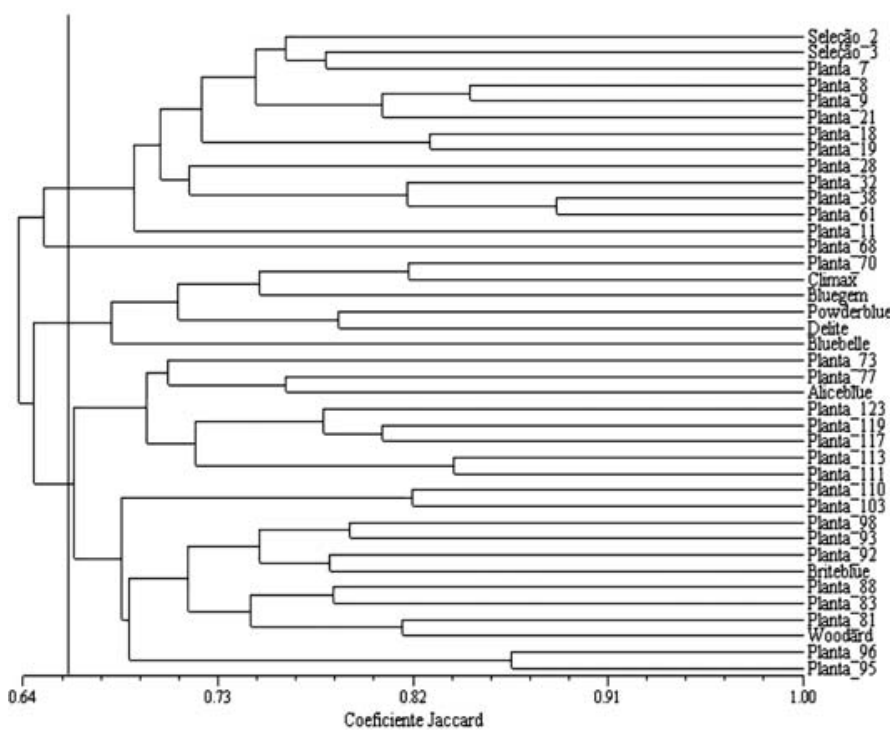

FIGURA 1- Dendrograma gerado a partir de marcadores de RAPD de 40 genótipos de mirtilo. Embrapa Clima Temperado, Pelotas-RS, 2007.

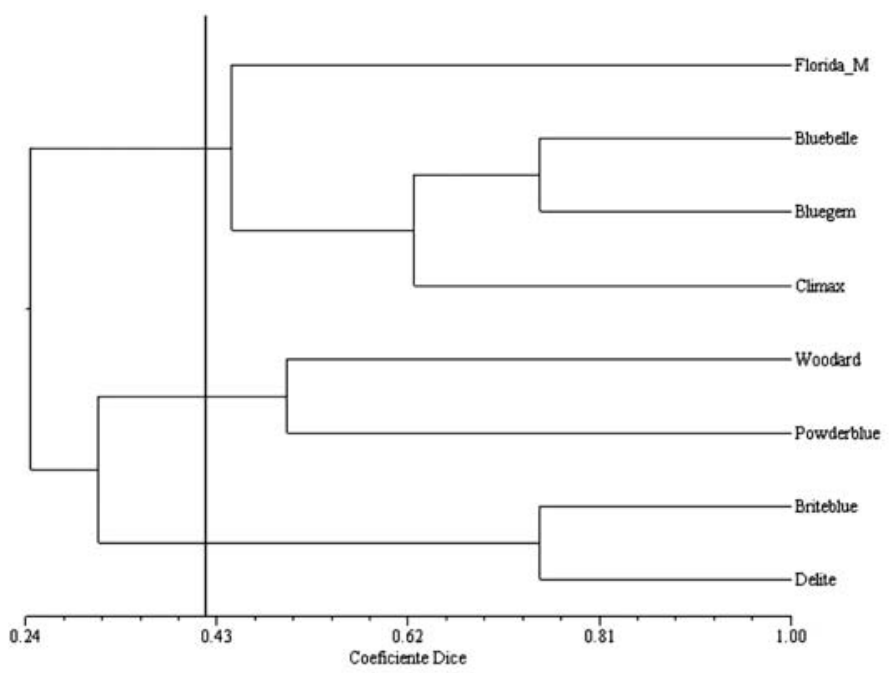

FIGURA 2 - Dendrograma gerado a partir de oito cultivares de mirtilo utilizando três pares de microssatélites. Embrapa Clima Temperado, Pelotas-RS, 2007.

\section{CONCLUSÃO}

Os marcadores do tipo RAPD e Microssatélites são eficientes na caracterização de genótipos de mirtilo.

\section{AGRADECIMENTO}

Os autores agradecem à Fundação de Amparo à Pesquisa do Estado do Rio Grande do Sul (FAPERGS), pelo apoio financeiro dado ao projeto 04.0668.7, Procoredes I, e ao Conselho Nacional de Desenvolvimento Científico e Tecnológico (CNPq), pela concessão de auxílio financeiro e bolsas de pesquisa (RD e PQ) aos autores do trabalho.

\section{REFERÊNCIAS}

ANTUNES, L.E.C.; MADAIL , J.C.M. Mirtilo: uma oportunidade de negócios. Disponível em: <http://www.todafruta.com.br/ todafruta/mostra_conteudo.asp? conteudo $=15206>$. Acesso em: 02 maio 2007.

AHMAD, R.; FERGUSON, L.; SOUTHWICK, S.M. Identification of pistachio (Pistacia vera L.) nuts with microsatellite markers. Journal American of the Society Horticultural Science, Alexandria, v.128, n.6, p.898-903, 2003.

BANÃDOS, M. P. Blueberry production in South America. Acta Horticulturae, Wageningen, n.715, p.165-172. 2006. Disponível em: < (http://www.actahort.org/books/715/715_24.htm)>.

BROCHES, P.; ROWLAND,L.; BASSIL, N. Est-derived microsatellites in Blueberry. In: CONFERENCE PLANT \& ANIMAL GENOMES, 12., 2004. San Diego, CA: Town \& Country Convention Center. Disponível em: <http://www.intl-pag.org/ 12/abstracts/P3b_PAG12_258.html >. Acesso: 22 jun. 2004.

BURGHER, K.L.; JAMIESON, A.R.; LU, X. Genetic relationships among Lowbush Blueberry Genotypes as determined by Randomly Amplified Polymorphic DNA Analysis. Journal American of the Society Horticultural Science, Alexandria, v.127, n.1, p. $98-103,2002$.

DUNEMANN, F; KAHNAU, R.; SCHMIDT, H. Genetic relationship in Malus evaluated by RAPD fingerprint of cultivars and wild species. Plant Breeding, Berlin, v.113, p. 150-159, 1994. ECK, P. Botany. In: ECK, P.; CHILDRES, N. (Ed.). Blueberry culture. Brunswick: Rutgers University, 1966. p.14-44.

FERREIRA, M.E.; GRATTAPAGLIA, D. Introdução ao uso de marcadores moleculares em análise genética. Brasília: EMBRAPA-CENARGEN, 1998.p.220.

GALDERISI, v.; CIPOLLARO, M.G.; MASI, C.B.L.; GALANO, G.; CASCINO, A. Molecular typing of Italian sweet chestnut cultivar by random amplified polymorphic DNA analysis. Journal 
of Science and Biotechnology, United Kingdom, v.73, n.2, p.259263.1998

GALLETTA, G.J.; BALLINGTON, J.R. Blueberry, cranberries and lingonberries In: JANICK, J.; MOORE, J.N.(Ed.). Fruit breeding. New York: J. Wiley \& Sons, 1996. p.1-108.

GRAHAM, J; SMITH, K., WOODHEAD, M.; RUSSELL, J. Development and use of simple sequence repeat SSR markers in Rubus species. Molecular Ecology Notes, Oxford, v.2, p.250-252, 2002

ORTIZ, A.; RENAUD, R.; CALZADA, I.; RITTER, E. Analysis of plum cultivars with RAPD markers. Journal of Horticultural Science, Alexandria, v.72, p.1-9, 1997.

RASEIRA, M. B. C., ANTUNES, L.E.C. A Cultura do mirtilo. Pelotas: Embrapa Clima Temperado, 2004. (Documento, 121)
ROWLAND,L. J.; DHANARAJ, A. L.; POLASHOCK, J.J.; ARORA, R. Utility of blueberry-derived EST-PCR primers in related Ericaceae species. IN Breeding,Cultivars,Rootstocks \& germplasm resources. HortScience, Alexandriam v.38, n 7, p. $1428-1432,2003$

SALLA, M. F. S.; RUAS, C. de F.; RUAS, P. M.; PÍPOLO V. C. Uso de marcadores moleculares na análise da variabilidade genética em acerola (Malpighia marginata D.C.). Revista Brasileira de Fruticultura, Jaboticabal, v.24, n.1,p.15-22, 2002.

SHIMADA, T.; HAYAMA, H.; HAJI, T.; YAMAGUCHI, M.; YOSHIDA, M. Genetic diversity of plums characterized by random amplified polymorphic DNA (RAPD)analysis. Euphytica, Dordrecht, v.109, p.143-147, 1999.

STRICK, B. Blueberry: an expanding world crop. Chronica horticulturae, Wageningen, v.45, n.1, p. 7-12, 2005. 